\title{
Impact of calcium associated to calcareous amendments on ectomycorrhizae in forests: A review
}

\author{
I. Monfort-Salvador ${ }^{1}$, L. G. García-Montero ${ }^{2 *}$, M.A. Grande ${ }^{3}$ \\ ${ }^{1}$ Departamento Ingeniería Forestal. Technical University of Madrid (UPM); E.T.S. Ingenieros de Montes, 28040 \\ Madrid, Spain. *Corresponding author: luisgonzaga.garcia@upm.es ${ }^{2}$ Departamento Ingeniería Forestal. Tech- \\ nical University of Madrid; U.D. Operaciones Básicas, E.T.S. Ingenieros de Montes, 28040 Madrid, Spain. \\ ${ }^{3}$ Deparment of Applied Physics. Technical University of Madrid (UPM); E.T.S. Ingenieros de Montes, 28040 \\ Madrid, Spain.
}

\begin{abstract}
There is currently little information available on calcium-soil-ectomycorrhizal (ECM) interactions. However, for decades calcareous amendments have been made in forest soils subject to acid rain in Europe without any clear knowledge of their impact on ECMs and the roots of their host plants. We have therefore performed a review to assess the impact of $\mathrm{Ca}$ associated to calcareous amendments in the soil-ECM-host plant system, which has highlighted: (1) the influence of $\mathrm{Ca}$ and its salts (carbonates and oxalates) of biological origin in ECM fungal communities; (2) the impact of $\mathrm{Ca}$ on the growth patterns of the host tree roots; (3) the importance for the plants of the rock-eating processes associated to ECMs; and (4) the impact on ECMs of the soil Ca cycle (associated to the litterfall). A greater knowledge of the cause-effect relations between Ca and the soil-ECM-plant system in Mediterranean and temperate forests could have positive repercussions on reforestation projects, actions associated to soil management, the commercial production of ECMs, and the economy of different rural zones in these forest areas.
\end{abstract}

Keywords: Ectomycorrhizas, Mediterranean forests, temperate forests, acid rain, rock-eating

\section{Introduction}

Calcareous amendments have been widely used in agroforestry management both tropical and temperate reforestations. For several decades the forestry industry has intensified its use of calcareous amendments to counteract the impact of acid rain in several forests in north and central Europe, which have a great abundance of ECM fungi. Several authors have warned of the lack of knowledge on the impact of the $\mathrm{Ca}$ associated to these calcareous amendments on the rhizosphere of these forests (Gronflaten et al., 2005; Naramabuye et al., 2008; Löfgren et al., 2009; Lee et al., 2011; Monfort-Salvador, 2013). 
There are known to be negative interactions between excess soil $\mathrm{Ca}$ and the processes of chlorosis in plants. A number of researchers have studied this chlorosis in pines, firs, apple trees, vines, peanuts, dwarf beans, green beans, soy, lupins and other plants (García-Montero et al., 2009). The abundance of finely divided calcium carbonate in the soil increases the levels of exchangeable $\mathrm{Ca}^{2+}$ and $\mathrm{HCO}_{3}^{-}$and generates a basic $\mathrm{pH}$, which precipitate $\mathrm{P}, \mathrm{B}, \mathrm{Fe}$ and $\mathrm{Mn}$ (Gaucher, 1971; Douchafour and Souchier, 1979; Follet et al., 1981; Loué, 1986; Wild, 1992; Callot, 1999).

The most important effect of liming is increase of soil $\mathrm{pH}$, moves out the $\mathrm{Al}^{3+}$ from the cationic exchange positions and hence reduces soil acidity, modify the Cationic and Anionic Exchange Capacity of the soils when they have and "variable change systems" (depending on the isoelectric point). However, calcareous amendments produce also reactions between the $\mathrm{Ca}^{2+}$ and $\mathrm{P}$ in the soil solution and in the soil colloids, and also cause secondary $\mathrm{Ca}$ carbonate precipitations. The degree of immobilisation of $\mathrm{P}$ by the $\mathrm{Ca}$ carbonate is inversely proportional to the size of its particles. Adding excess $\mathrm{Ca}^{2+}$ and $\mathrm{HCO}_{3}^{-}$in the soil can cause $\mathrm{Mg}^{2+}$ deficiencies in plants (Follet et al., 1981), and generate secondary calcites that also immobilise $\mathrm{Mg}^{2+}$ (Douchafour and Souchier, 1979).

Borja and Nilsen (2009) and Bakker et al. (2000) indicate that calcareous amendments may have a long-term impact on forest rhizospheres, as they have observed that the effects are evident 27 and 35 years after application, respectively. For this reason, more knowledge is also needed on the impact of calcareous amendments on ECM fungi in the forest environment; this has been a matter of increasing concern in the scientific literature in recent decades (Erland and Söderström, 1990; Schneider and Zech, 1990; Antibus and Linkins, 1992; Huettl and Zoettl, 1993; Kreutzer, 1995; Jonsson et al., 1999; Bakker et al., 2000).

The present review aims to contribute to the knowledge of the interactions between $\mathrm{Ca}$ associated to calcareous amendments and soilECM-plant systems, and to assess the potential impact of liming on forest rhizospheres.

\section{Effect of calcareous amendments on forest scale}

\subsection{Interaction between calcareous amendments and soil nutrients}

After calcareous amendments, it has been observed that one of the main effect of the amendments is that they provoke an increase in soil $\mathrm{pH}$ (Borja and Nilsen, 2009; Rineau and Garbaye, 2009) (Table 1).

Calcareous amendments increase concentrations of $\mathrm{Fe}, \mathrm{K}, \mathrm{Si} \mathrm{Ca}, \mathrm{Mg}$ and $\mathrm{Mn}$ in the soil because of their previous presence in carbonate rocks that constitute the raw material of amendments (Table 1). Rineau and Garbaye (2009) and Rineau et al. (2010b) indicate that in the control plots in their study, the initial concentrations of $\mathrm{Ca}, \mathrm{Mg}$ and $\mathrm{Mn}$ were low or very low. However, after calcareous amendments these three nutrients were the elements whose concentration had increased most. Rineau et al. (2010b) did not observe any change in $\mathrm{Na}, \mathrm{S}$ and $\mathrm{P}$ concentrations after the amendments. 
Rineau et al. (2010b) indicate that in some plots with acid soils of Fagus sylvatica L. mycorrhized with Lactarius subdulcis (Pers.: Fr.) S.F. Gray, calcareous amendments produced an increase in Al levels in the soil. Qian et al. (1998) made additions of sulphuric acid and calcareous amendments (obtained from dolomites) in formations of Picea abies (L.) Karst. These authors also observed high concentrations of Al in the soil, accompanied by high mycorrhizal activity. In contrast, in several plots of Pinus sylvestris L. and Fagus sylvatica associated with ECM fungi, Rineau and Garbaye (2009) observed a decrease in soil Al concentrations, although they did not venture any explanation of these findings. However, it is necessary to note that the interactions between calcareous amendments and exchangeable Al are a complex question in soil chemistry, strongly dependent on soil genesis and local soil processes.

Table 1. Comparison of the effects of calcareous amendments on soil nutrients: $(>)$ increased concentration; $(<)$ decreased concentration; $(=)$ the concentration remains the same (soil elements when the calcareous amendments occur)

\begin{tabular}{|c|c|c|c|c|c|c|c|c|c|c|c|c|c|c|c|}
\hline Authors & Host species & $\begin{array}{l}\text { ECM } \\
\text { species }\end{array}$ & $\mathrm{Ca}$ & $\mathrm{Mn}$ & $\mathrm{Al}$ & $\mathrm{Fe}$ & $\mathrm{Mg}$ & K & $\mathrm{Na}$ & $\mathrm{S}$ & $P$ & $\mathrm{pH}$ & $\mathrm{N}$ & $\mathrm{Si}$ & $\mathrm{C}$ \\
\hline $\begin{array}{l}\text { Rineau et al. } \\
(2010 \mathrm{~b})\end{array}$ & Fagus sylvatica & $\begin{array}{l}\text { Lactarius } \\
\text { subdulcis }\end{array}$ & $>$ & $>$ & $>$ & $>$ & $>$ & $>$ & $=$ & $=$ & $=$ & & & $>$ & \\
\hline $\begin{array}{l}\text { Rineau and } \\
\text { Garbaye } \\
\text { (2009) }\end{array}$ & $\begin{array}{l}\text { Fagus sylvatica } \\
\text { Picea Abies }\end{array}$ & - & $>$ & $>$ & $<$ & & $>$ & & & & & $>$ & $<$ & & $<$ \\
\hline $\begin{array}{l}\text { Andersson, } \\
\text { Jensé and } \\
\text { Söderström } \\
\text { (1996) }\end{array}$ & $\begin{array}{l}\text { Picea Abies } \\
\text { Betula péndulas }\end{array}$ & $\begin{array}{l}\text { Paxillus } \\
\text { involutus } \\
\text { Batsch : } \\
\text { Fr. }\end{array}$ & $>$ & & $=$ & & $>$ & & & & $<$ & $>$ & & & \\
\hline $\begin{array}{l}\text { Kjoller and } \\
\text { Clemmensen } \\
\text { (2009) }\end{array}$ & $\begin{array}{l}\text { Pinus sylvestris } \\
\text { and Picea abies }\end{array}$ & - & & & $<$ & & & & & & & $>$ & & & \\
\hline
\end{tabular}


Table 2. ECM species whose natural populations increase in response to calcareous amendments

\begin{tabular}{|c|c|c|}
\hline Authors & ECM species & Host species \\
\hline Kjoller and Clemmensen, (2009) & $\begin{array}{l}\text { Amphinema. Byssoides } \\
\text { (Pers.) J. Erikss. }\end{array}$ & Coniferous \\
\hline Rineau and Garbaye (2009) & $\begin{array}{l}\text { Amanita rubescens } \\
\text { (Pers.: Fr.) S.F. Gray }\end{array}$ & $\begin{array}{l}\text { Fagus sylvatica y Picea } \\
\text { spp. }\end{array}$ \\
\hline Kjoller and Clemmensen (2009) & Atheliaceae sp. & Coniferous \\
\hline Rineau, et al. (2010a) & $\begin{array}{l}\text { Clavulina cristata } \\
\text { (Holmsk.) J. Schröt }\end{array}$ & $\begin{array}{l}\text { Fagus sylvatica y Picea } \\
\text { spp. }\end{array}$ \\
\hline Jonsson et al. (1999) & Cortinarius sp. & Picea abies \\
\hline Kjoller and Clemmensen (2009) & Elaphomyces sp & Coniferous \\
\hline Jonsson et al. (1999) & $\begin{array}{l}\text { Hebeloma } \\
\text { crustiliniforme } \\
\text { (Bulliard) Quélet }\end{array}$ & Picea abies \\
\hline Rineau et al. (2010a) & Lactarius subdulcis & $\begin{array}{l}\text { Fagus sylvatica y Picea } \\
\text { spp. }\end{array}$ \\
\hline Kjoller and Clemmensen (2009) & Pezizales sp. & Coniferous \\
\hline $\begin{array}{l}\text { Kjoller and Clemmensen (2009); Qian, Kottke and } \\
\text { Oberwinkler (1998) }\end{array}$ & Piceirhiza nigra & Coniferous \\
\hline Rineau and Garbaye (2009) & $\begin{array}{l}\text { Sebacina epigeia (Berk. } \\
\& \text { Broome) Neuhoff }\end{array}$ & $\begin{array}{l}\text { Fagus sylvatica y Picea } \\
\text { sp. }\end{array}$ \\
\hline Kjoller and Clemmensen (2009) & $\begin{array}{l}\text { Tylospora asterophora } \\
\text { (Bonord.) Donk }\end{array}$ & Coniferous \\
\hline Kjoller and Clemmensen (2009) & Tomentella sp & Coniferous \\
\hline Rineau et al. (2010a) & $\begin{array}{l}\text { Tomentella sublilacina } \\
\text { (Ellis \& Holw.) Wakef. }\end{array}$ & $\begin{array}{l}\text { Fagus sylvatica y Picea } \\
\text { sp. }\end{array}$ \\
\hline Rineau et al. (2010a) & Tricholoma sp. & $\begin{array}{l}\text { Fagus sylvatica y Picea } \\
\text { sp. }\end{array}$ \\
\hline $\begin{array}{l}\text { Kjoller and Clemmensen (2009); Qian, Kottke and } \\
\text { Oberwinkler (1998) }\end{array}$ & Tuber cf. puberulum & Coniferous \\
\hline Jonsson et al. (1999) & $\begin{array}{l}\text { Tylopilos felleus (Bull.: } \\
\text { Fr.) Karsten }\end{array}$ & Picea abies \\
\hline Qian, Kottke and Oberwinkler (1998) & $\begin{array}{l}\text { Tylospora fibrillosa } \\
\text { (Burt) Donk, }\end{array}$ & Picea abies \\
\hline
\end{tabular}

\subsection{Effects of calcareous amendments on the ectomycorrhization of trees}

The application of calcareous amendments in natural populations of Pinus sylvestris, Picea abies, Quercus petraea (Mattuschka) Liebl. and Q. robur L. have triggered an increase in the number of roots colonised by ECMs; this appears to be related to an increase in soil calcium carbonate and $\mathrm{pH}$ (Erland and
Söderström, 1990; Nowotny et al., 1998; Bakker et al., 2000; Borja and Nilsen, 2009). With regard to this effect, Andersson et al. (1996) observed that increased colonisation of ECMs in the host tree roots brings a corresponding increase in the roots' absorption of $\mathrm{Ca}$. In contrast, calcareous amendments have a negative effect on ECM biodiversity. The main ECMs affected by calcareous amendments are acidophilic species which are displaced due to the disappearance of their 
ecological niches caused by the increase in soil $\mathrm{Ca}$ and $\mathrm{pH}$ (Erland and Söderström, 1990; Bakker et al., 2000; Borja and Nilsen, 2009; Rineau and Garbaye, 2009). This modification of the ECM community may be harmful to species of ECM fungi under threat of extinction (Kjoller and Clemmensen, 2009). Tables 2, 3 and 4 compare the ECM species that have been affected by calcareous amendments, positively or negatively, compared to the species of ECMs that were shown to be unaffected.

The amendments appear to have a different effect on the different ECM morphotypes present in the host tree roots. Mycorrhizas without cystidia (smooth morphotypes) such as Lactarius spp. and Russula spp. decrease their abundance, whereas calcareous amendments appear to have a positive effect on mycorrhizas with cystidia (rough morphotypes), which spread their colonisation to new roots (Bakker et al., 2000). However, Rineau et al. (2010a) observed an increase in the ECMs of Lactarius subdulcis in plots of Fagus sylvatica and Picea spp. (Table 2).

The impact of calcareous amendments on ectomycorrhized roots could be due to the fact that increasing doses of calcium carbonate promote meristematic root cell activity and increase the length of the fine roots. This process appears to be related with an increase in drought resistance observed in various trees in plots treated with calcareous amendments (Qian et al., 1998; Bakker et al., 2000; Rineau et al., 2010a).

Table 3. ECM species whose natural populations decrease in response to calcareous amendments

\begin{tabular}{|c|c|c|}
\hline Authors & ECM species & Host species \\
\hline & Cenococcum geophilum & \\
\hline Rineau et al. (2010a) & Fr. & Fagus sylvatica y Picea sp \\
\hline Rineau y Garbaye (2009) & Clavulina cristata & Fagus sylvatica y Picea sp \\
\hline Rineau et al. (2010a) & Cortinarius spp & Fagus sylvatica y Picea sp \\
\hline Rineau et al. (2010a) & Dermocybe spp. & Fagus sylvatica y Picea sp \\
\hline Kjoller y Clemmensen (2009); Rineau et al. (2010a) & Lactarius spp & Coniferous \\
\hline Jonsson et al. (1999) & $\begin{array}{l}\text { Lactarius necátor } \\
\text { (Bull.) Pers }\end{array}$ & Picea abies \\
\hline Rineau y Garbaye (2009) & Lactarius tabidus Fr. & Fagus sylvatica y Picea sp \\
\hline Rineau et al. (2010a) & Paxillus spp. & Fagus sylvatica y Picea sp \\
\hline Rineau et al. (2010a) & Piceirhiza spp. & Fagus sylvatica y Picea sp \\
\hline Kjoller y Clemmensen (2009); Rineau et al. (2010a) & Russula sp. & Coniferous \\
\hline Rineau et al. (2010a) & Russula nigricans & Fagus sylvatica y Picea sp \\
\hline Jonsson et al. (1999); Rineau et al. (2010a) & $\begin{array}{l}\text { Russula ochroleuca } \\
\text { Thelephora terrestres }\end{array}$ & Picea abies \\
\hline Jonsson et al. (1999) & Ehrh & Picea abies \\
\hline Rineau y Garbaye (2009) & $\begin{array}{l}\text { Xerocomus pruinatus } \\
\text { (Fr.) Quel. }\end{array}$ & Fagus sylvatica y Picea sp \\
\hline
\end{tabular}


Table 4. ECM species whose natural populations do not change in response to calcareous amendments

\begin{tabular}{|c|c|c|}
\hline Authors & ECM species & Host species \\
\hline Jonsson et al. (1999) & Boletus. Chrysenteron Bull. & Picea abies \\
\hline Rineau et al. (2010a) & $\begin{array}{l}\text { Cantharella sp. } \\
\text { Cortinarius anomalus (Fr.: Fr.) }\end{array}$ & Fagus sylvatica y Picea sp. \\
\hline Rineau et al. (2010a) & Fr. & Fagus sylvatica y Picea sp. \\
\hline Kjoller y Clemmensen (2009) & $\begin{array}{l}\text { Cortinarius spp. } \\
\text { Hygrophorus olivaceoalbus (Fr.) }\end{array}$ & Coniferous \\
\hline Rineau et al. (2010a) & $\begin{array}{l}\text { Fr. } \\
\text { Laccaria amethystina (Bull.) }\end{array}$ & Fagus sylvatica y Picea sp. \\
\hline Rineau et al. (2010a) & Murr. & Fagus sylvatica y Picea sp. \\
\hline Andersson, Jensé y Söderström (1996) & Paxillus involutus & Picea abies y Betula pendula \\
\hline Kjoller y Clemmensen (2009) & Piceirhiza nigra & Coniferous \\
\hline Qian, Kottke y Oberwinkler (1998) & $\begin{array}{l}\text { Russula ochroleuca } \\
\text { Sebacina epigaea } \text { Berk. \& }\end{array}$ & Picea abies \\
\hline Rineau et al. (2010a) & Broome) Neuhoff & Fagus sylvatica y Picea sp. \\
\hline Jonsson et al. (1999) & Tylospora fibrillosa & Picea abies \\
\hline
\end{tabular}

2.3 Other effects of calcareous amendments on ECM fungi

Rineau and Garbaye (2010) and Rineau et al. (2010b) report that the ECMs of Lactarius spp. have the capacity to segregate significant quantities of laccase and calcium oxalate $\mathrm{CaOx}$. In their view this explains the accumulations of $\mathrm{CaOx}$ crystals observed around the root systems of trees mycorrhized with Lactarius spp. in plots treated with calcareous amendments.

Rineau and Garbaye (2009) and Rineau et al. (2010a) studied the production of fruiting bodies by ECM fungi in plots treated with calcareous amendments, and report that acidophilic ECMs species fruited closer to the stem of the trees where the soil was more acid. These authors propose Russula ochroleuca (Pers.) Fr. as a possible marker species of the effect of calcareous amendments due to the easy identification of its ECMs and the appearance of its carpophores around the trunk of its host trees. Elsewhere, Jonsson et al. (1999) and Rineau et al. (2010a) did not observe any relation between the biomass of the ECM mycelium and the production of their fruiting bodies; these same authors also report that this lack of correlation hinders the work of ECM sampling.

García-Montero et al. (2009) in the field of truffle cultivation. These authors showed that the application of these amendments in plantations of Tuber melanosporum Vittad. and T. brumale Vittad. associated to Quercus spp. caused a rapid and significant rise in truffle production. However, they pointed out the need for exhaustive studies before applying calcareous amendments in truffle production, owing to lack of knowledge on the potential longterm effects on soil properties and ECM communities.

\section{Impact of available soil calcium on the biology of ecm fungi}

García-Montero et al. (2009) observed that accumulations of $\mathrm{Ca}$ and finely divided calcium carbonate (active lime) occur in the rhizosphere of trees mycorrhized by several truffle species (Tuber melanosporum and T. brumale). García-Montero et 
al. (2009), therefore, that the ECMs of both these species cause a natural process which is equivalent to "calcareous amendments" to favour their mycorrhization and fruiting. In contrast, low levels of exchangeable $\mathrm{Ca}$ and/or soil $\mathrm{pH}$ cause a slowdown in the development of summer truffles (T. aestivum Vittad.) (Wedén et al., 2009). Furthermore, Aponte et al. (2010) report that high levels of $\mathrm{Ca}$ and soil $\mathrm{pH}$ observed in some natural populations of Quercus suber L. and $Q$. canariensis Willd. bear a significant relation with low levels of diversity in the ECM species that colonise them. All these findings suggest that soil $\mathrm{Ca}$ is associated with the dynamics of the ECM fungal communities.

When $\mathrm{Ca}$ is present in low concentrations in the soil, several species of ECM fungi increase the mobilisation, transport and absorption of $\mathrm{Ca}$ by the host trees. These observations explain the finding in experimental plots that $\mathrm{Ca}$ concentrations are greater in ectomycorrhized trees than in trees without ECM fungi, when $\mathrm{Ca}$ soil availability is low. In these experiments, several authors have shown that the rhizosphere of the ectomycorrhized trees reveals (1) the formation of calcium deposits in the roots, (2) an increase in soil $\mathrm{pH}$, and (3) increased calcium in the litterfall deposited on the soil. Furthermore, different species of ECM fungi can accumulate different amounts of $\mathrm{Ca}$ in their mycelium, and as the mycelium of the ECM fungi gradually dies, the accumulation of $\mathrm{Ca}$ present in its hyphae are mixed with the soil, thereby increasing the amount of available Ca (Andersson et al., 1996; Aroncena and Glowa, 2000; Zambrano et al., 2009).

\section{4. "Rock-eating" processes associated to ecms and their impact on soil ca}

Several authors propose the term "rock-eating" to describe the formation of micro-channels (3 to $10 \mu \mathrm{m}$ in diameter) made by the ECM hyphae in feldspar and hornblende rocks rich in $\mathrm{K}, \mathrm{Ca}$ and $\mathrm{Mg}$ (Jongmans et al., 1997; Van Breemen et al. 2000a; Blum et al., 2002; Hoffland et al., 2003; Van Schöll et al., 2008). Wallander et al. (2003) and Smits et al. (2012) have demonstrated that the meteorization of apatite increases with the activity of ECM fungi. These authors indicate that these "rock-eating" processes allow ECM fungi to extract $\mathrm{Ca}$ and other nutrients from rocks.

This rock-eating process has not been associated with any types of mycorrhizas other than ECMs. Hoffland et al. (2003) and Van Schöll et al. (2008) report that endomycorrhizal fungi have very little capacity to absorb Ca from rocks. Blum et al. (2002) describe natural populations of Acer spp. associated to endomycorrhizas that have a low capacity to access soil $\mathrm{Ca}$, even though this tree species is highly sensitive to Ca deficit. Hoffland et al. (2003) and Van Schöll et al. (2008) also rule out the involvement of the hyphae of arbuscular fungi in rock-eating processes. In this regard, arbuscular mycorrhizal association plays a key role in the sustainability of terrestrial plant ecosystems, in particular those presenting limitations for the establishment and subsequent growth of plants (Borie et al., 2010). However, a number of authors consider it unlikely that ericoid and saprophytic fungi are involved in these rock-eating processes (Jongmans et al., 1997; Hoffland et al., 2003; Van Schöll et al., 2008).

Rock-eating processes of ECM fungi seem to be associated to a deficit of certain nutrients $(\mathrm{K}, \mathrm{Ca}$ and $\mathrm{Mg}$ ) in the soil (Van Breemen et al., 2000a, 2000b; Hoffland et al., 2002; Wallander et al., 2006; Van Schöll et al., 2008). These rock-eating processes begin with the appearance of small cracks or etch-pits on the rock surfaces caused by the secretion of acids (succinate, citrate, oxalate, formate and malate) from the hyphae of ECM fungi (Jongmans et al., 1997; 
Hoffland et al., 2003). The density of the microtunnels observed in feldspar rocks is correlated with the amount of fine roots existing in the rhizosphere (Hoffland et al., 2003). In certain soils, in one year it is estimated that an average of $166 \mathrm{~m}$ of micro-tunnels can be formed per $\mathrm{dm}^{3}$ of rock (Van Breemen et al., 2000a). Van Schöll et al. (2008) indicate that there is a different concentration of the ECM hyphae in direct contact with the rock depending on its mineralogical composition. There is an increasing abundance of hyphae in rocks with a mineral concentration following the gradient: $\mathrm{Na} / \mathrm{Ca}$-feldspar $>\mathrm{K}$-Feldspar $>$ quartz.

With regard to their position in soils, the greatest rockeating activity and formation of micro-tunnels by the ECMs occurs in the upper part of the E horizons (Hoffland et al., 2002; Hoffland et al., 2003; Van Schöll et al., 2008).

Blum et al. (2002) indicate in regard to the soil-ECMtree system that rock-eating processes explain the significant quantities of $\mathrm{Ca}$ observed in the leaves of mixed conifer and broadleaved forests in Ca-poor soils. These authors note that the $\mathrm{Ca}$ accumulated in the leaves came from apatite rocks.

\section{Calcium oxalate concentration in the rhizosphere and hyphae of ecms}

Zambrano et al. (2009) observe that various roots colonised by ECMs revealed accumulations of calcium oxalate crystals $(\mathrm{CaOx})$, with a greater abundance (and larger crystals) than in roots without ECMs. These authors also indicate that the amount of $\mathrm{Ca}^{2+}$ and oxalic acid available in the soil of the rhizosphere determines the size of the $\mathrm{CaOx}$ crystals. A number of authors report that these accumulations of $\mathrm{CaOx}$ are concentrated preferentially on the tips of the ectomycorrhizas and on the hyphae of their fungi, in response to the high concentrations of calcium in the soil and/or to the abundance of rocks with apatite minerals (Aroncena et al., 2001; Wallander et al., 2003; Zambrano et al., 2009; Rineau and Garbaye, 2010; Smits et al., 2012). Specifically, it has been observed that ECM fungi with extramatricial mycelium such as Piloderma croceum Erikss. \& Hjortst. accumulate a greater amount of $\mathrm{CaOx}$ crystals than fungi without extramatricial mycelium such as Tomentellopsis submollis Svrcek. (Weigt et al., 2011).

The morphology and distribution of $\mathrm{CaOx}$ crystals vary with diverse ECM morphotypes. In the case of Piloderma species, differences were found between the quantities of $\mathrm{CaOx}$ accumulated in the rhizosphere on plots studied in the field, and the rhizosphere in plants in the laboratory. This observation was related to the higher number of roots counted in the natural environments in the study (Aroncena et al., 2001; Wallander et al., 2003; Tuason and Aroncena, 2009; Zambrano et al., 2009).

There is also a relationship between the formation of $\mathrm{CaOx}$ crystals and the abundance of $\mathrm{P}$ in the soil; thus when $\mathrm{P}$ was found in limiting conditions for the rhizosphere, the abundance of $\mathrm{CaOx}$ crystals formed in the ECM hyphae depended on the level of available soil Ca (Mrnka et al., 2009). A significant relation was observed between the relatively high concentrations of $\mathrm{Ca}(5 \mathrm{mM})$ and low concentrations of $\mathrm{P}(0.1 \mathrm{mM})$ in the soil, and the accumulation of high quantities of $\mathrm{CaOx}$ in the rhizospheres. However, in soils with high levels of $\mathrm{P}$, the formation of $\mathrm{CaOx}$ crystals was abundant in relation to all values of soil $\mathrm{Ca}$ (except in cases where there was no Ca) (Wallander, 2000; Tuason and Aroncena, 2009).

\section{Effect of ca in the roots of ecm host trees}

$\mathrm{Ca}$ accumulation has been observed to occur in the root after calcareous amendments, linked to its increasing concentration in the soil, and according to 
Andersson et al. (1996), the increased calcium in the roots is distributed throughout the whole of the root system, with no differences noted between the fine roots and the rest; whilst Bakker et al. (2000) observed a significant effect of calcareous amendments on root development in Quercus petraea and Q. robur, which depended on the dose, the type and the age of the plants, and the time elapsed between the amendments and the root sampling. Ostonen et al. (2009) found that in ECM host trees, the diameter of the rootlets increases in relation with the concentrations of available soil $\mathrm{Ca}$ and $\mathrm{N}$.

In a study of the concentration of various elements present in the roots in several forests of Fagus sylvatica, Fraxinus excelsior L. and Tilia sp. in central Europe, Lang and Polle (2011) and Mrnka et al. (2009) noted that root biodiversity plays a key role in the concentrations of root $\mathrm{Ca}, \mathrm{K}, \mathrm{P}, \mathrm{Mg}$ and $\mathrm{Fe}$. Thus the concentration of $\mathrm{Ca}$ found in the rhizosphere of Fagus sylvatica was significantly higher in areas where the roots of the tree were growing alongside the roots of other species. Jentschke et al. (1998) and Zambrano et al. (2009) indicate that the absorption of soil Ca through roots is depressed by the abundance of soil ammonium, $\mathrm{K}, \mathrm{Mg}$ and $\mathrm{Al}$, and by low $\mathrm{pH}$ values.

\section{Effect of ca on the leaves and stems of ecm host trees}

Weigt et al. (2011) observed that in various seedlings ectomycorrhized with Tomentellopsis submollis the $\mathrm{Ca}$ concentrations in the stem shoots were greater than the shoots in the seedlings ectomycorrhized with Piloderma croceum. In contrast, the roots ectomycorrhized with $P$. croceum had a higher amount of $\mathrm{Ca}$ than the roots ectomycorrhized with Tomentellopsis submollis.

Ba et al. (2002) and Mrnaka et al. (2009) report that ECM fungi increase the content of nutrients $(\mathrm{Ca}, \mathrm{N}$, $\mathrm{P}, \mathrm{K})$ in the leaves of certain trees. However these authors also observed a delayed biomass development in these ectomycorrhized trees.

Other authors have noted a positive correlation between levels of available soil $\mathrm{Ca}$ (associated to experimental calcareous amendments), and $\mathrm{Ca}$ concentrations found in the needles of various Pinus spp. and the leaves of Betula spp. (Andersson et al., 1996; Casarin et al., 2004; Borja and Nilsen, 2009). However, Zhang and George (2002) report that in various plots of Picea abies no correlation was detected between $\mathrm{Ca}$ concentrations in their needles and the calcareous doses added into the soil. These authors suggest as an explanation that soil $\mathrm{Al}$ acts as an inhibitor of $\mathrm{Ca}$ absorption by Picea abies. In this regard, Meriño-Gergichevich et al. (2010) indicated that, as result of the negative effects of toxic $\mathrm{Al}$, root metabolic processes, such as water and nutrient absorption, are disturbed with a concomitant decrease in Ca uptake.

Blum et al. (2002) determined that the amount of $\mathrm{Ca}$ measured in the leaves of trees is significantly related to the $\mathrm{Ca}$ extracted and mobilised from feldspar rocks by ECM fungi colonising those trees (through rockeating processes).

These observations vary based on the species of ECM fungi in question. Mrnaka et al. (2009) observed that the levels of $\mathrm{Ca}$ increased significantly in the needles of populations of Picea abies that were mycorrhized by Hebeloma bryogenes Vesterh. and Setulipes androsaceus $\mathrm{L}$.

Other authors confirm that the Ca present in the leaves may trigger changes in available soil Ca content (when the litterfall is incorporated). Thus the soil is modified by the interactions between different tree species and species of ECM fungi, as each species has a different capacity for absorbing and retaining $\mathrm{Ca}$ (Blum et al., 2002; Hobbie et al., 2006; Aponte et al. 2010).

Specifically, Aponte et al. (2010) indicated that certain deciduous species such as Quercus canariensis 
incorporate more soil $\mathrm{Ca}$ in their leaves than other perennial species such as $Q$. suber. The same pattern has been observed by other authors in natural populations of Betula pendula Roth. (deciduous species) versus Picea abies (perennial species) in plots treated with calcareous amendments (Andersson et al., 1996).

Aponte et al. (2010) also explained that the differences observed between $\mathrm{Ca}$ accumulated in the leaves of one deciduous tree species compared to the leaves of one perennial tree species could account for the variations in the amount of available soil $\mathrm{Ca}$ (associated to the litterfall) at the base of deciduous trees in comparison with the soil $\mathrm{Ca}$ at the base of perennial trees. The litterfall from Quercus canariensis supplies 81\% more $\mathrm{Ca}$ to the soil than the litterfall from $Q$. suber. These authors point out that these differences in the Ca concentrations of the litterfall can lead to selective environmental conditions that would modify the composition of ECM fungal communities.

Aponte et al. (2010) confirmed the existence of a negative relationship between the taxonomical biodiversity of ECMs and the $\mathrm{Ca}$ concentration in the litterfall from their host trees. In contrast, Borja and Nilsen (2009) did not find any significant relation between the amount of nutrients present in the aciculae of Pinus sylvestris and the degree of colonisation of their ECM communities.

\section{Discussion}

The scarcity of knowledge on the interactions between $\mathrm{Ca}$ and ECM fungi has led several authors to highlight the need for new studies on (1) the interaction of litterfall with ECM fungi communities (Aroncena and Glowa, 2000), (2) the interaction of soil $\mathrm{Ca}$ and ECM communities (García-Montero et al., 2009), (3) the accumulation of $\mathrm{CaOx}$ crystals associated to ECMs (Tuason et al., 2009), (4) the interaction of $\mathrm{Ca}$ and tree roots (Lang and Polle, 2011), and (5) the interaction of ECM rock-eating processes in the nutrition of their host trees (Van Schöll et al., 2008).

The present review reveals that the primary effects of calcareous amendments on ECM fungi communities are, in general: (1) a decrease in their biodiversity (particularly in acidophilic fungi), and (2) an increase in the total colonisation of the roots of host trees by the ECM fungi. Calcareous amendments have varying impacts on ECM communities according to the species and morphotypes of the ECMs, but do not generally have any significant effect on the production of fruiting bodies. Similarly, in experimental plots subject to acid rain, the decrease in soil $\mathrm{pH}$ was not found to influence the production of ECM fungi (Agerer et al., 1998). However, the increase in $\mathrm{pH}$ and $\mathrm{Ca}$ associated to the litterfall from the trees causes variations in the dynamics of ECM fungal communities, and in some cases, a decrease in their carpophore production.

Thy hyphae of ECM fungi are capable of counteracting the lack of $\mathrm{Ca}$ and other nutrients in the soil through rock-eating processes. Jongmans et al. (1997) and Van Breemen et al. (2000) report that the rock-eating processes of ECMs could explain the continued productivity of European forestry in areas affected by acid rain in recent decades. These authors therefore consider the application of calcareous amendments to possibly be unnecessary in acid soils in these regions of Europe.

Certain ECM fungi are capable of accumulating $\mathrm{Ca}$ (or its salts) in the rhizosphere. However, there is little knowledge of the causes that provoke these natural accumulations of $\mathrm{Ca}$. Tuason and Aroncena (2009) and Smits et al. (2012) proposed that these accumulations of $\mathrm{Ca}$ in the rhizosphere could be a precautionary mechanism by ECMs when their soil concentrations decrease. However, the rock-eating activity of ECMs would make it unnecessary to deploy mechanisms for the accumulation of $\mathrm{Ca}$ in 
order to prevent deficiencies (Wallander et al., 2006; Van Breemen et al., 2000a). Casarin et al. (2004) suggests that the natural accumulation of $\mathrm{Ca}$ in the rhizosphere of Pinus pinaster Ait. could be a "barriereffect" mechanism by the ECMs that would protect the tree by preventing the absorption of $\mathrm{Ca}$ by its roots. Whitney and Arnott (1987) also attribute the accumulations of $\mathrm{CaOx}$ to a process of protection of the rhizosphere in response to possible attacks by microbes or by soil fauna.

Finally, several authors have ventured new hypotheses in relation to the interactions between Ca, ECM communities, and other groups of organisms present in forest rhizospheres:

Earthworms may produce the same effect as calcareous amendments on forest rhizospheres, as on the one hand (1) they homogenise the soil, thereby increasing its $\mathrm{pH}$ (Qian et al., 1998; Rieneau and Garbaye, 2009); and furthermore (2) earthworms cause an increase in soil calcium carbonate from their calciferous glands (which they all possess). These glands produce a net fixation of $\mathrm{C}$ in the soil (from fresh organic matter and $\mathrm{CO}_{2}$ ) and an increase in soil pH (Canti, 2009; García-Montero et al. 2013). These actions by earthworms would have a similar impact to the effects described for calcareous amendments, as they would similarly modify the nutrients of the forest rhizospheres, alter their ECM communities and modify the growth patterns of the roots.

Certain populations of ECM fungi have the capacity to accumulate $\mathrm{Ca}$ in the rhizosphere, which could provoke chlorosis in their host trees and favour their mycorrhization according to a feedback model proposed by García-Montero et al. (2009).

\section{Conclusion}

In conclusion, the present work underlines the fact that soil calcium (and its salts: carbonates and oxalates) have an impact on the interaction between ECM fungi and host trees. It particularly highlights the impact of calcium on (1) growth patterns in roots and (2) ECM population dynamics. Another noteworthy finding is the importance of $\mathrm{Ca}$ cycles (1) in relation to its accumulation and mobilisation by leaves and litterfall, and (2) due to the rockeating processes associated to ECMs. However, there are still many unanswered questions with regard to the cause-effect relationships between the interactions of $\mathrm{Ca}$ and the soil-ECM-plant system in Mediterranean and temperate forests. A greater knowledge of these interactions would have positive repercussions for reforestation projects, soil management actions in these forests, commercial production and harvesting of ECM fungi, and the economy of the various rural areas in these regions.

\section{References}

Agerer, R., Taylor, A.F.S., Treu, R. 1998. Effects of acid irrigation and liming on the production of fruit bodies by ectomycorrhizal fungi. Plant Soil 199, 83-89.

Andersson, S., Jensén, P., Söderström, B. 1996. Effects of mycorrhizal colonization by Paxillus involutus on uptake of $\mathrm{Ca}$ and $\mathrm{P}$ by Picea abies and Betula pendula grown in unlimed and limed peat. New Phytol 133, 695-704.

Antibus, R.K., Linkins, A.E. 1992. Effects of liming a red pine forest floor on mycorrhizal numbers and mycorrhizal and soil acid phosphatase activities. Soil Biol Biochem 24, 479-487.

Aponte, C., García, L.V., Marañon, T., Gardes, M. 2010. Indirect host effect on ectomycorrhizal fungi: Leaf fall and litter quality explain changes in fungal communities on the roots of cooccurring Mediterranean oaks. Soil Biol Biochem 42, 788-796. 
Aroncena, J.M., Glowa, K.R. 2000 .Mineral weathering in ectomycorrhizosphere of subalpine (Abies lasiocarpa (Hook.) Nutt.) as revealed by soil solution composition. For Ecol Manag 133, 61-70.

Aroncena, J.M., Glowa, K.R., Massicotte, H.B. 2001. Calcium-rich hypha encrustations on Piloderma. Mycorrhiza 10, 209-215.

Bâ, A.M., Sanon, K.B., Duponnois, K.B. 2002. Influence of ectomycorrhizal inoculation on Afelia quanzansis Welw. Seedlings in a nutrientdeficient soil. For Eco Manag 161, 215-219.

Bakker, M.R., Garbaye, J., Nys, C. 2000. Effect of liming on the ectomycorrhizal status of oak. For Eco Manag 126, 121-131.

Blum, J.D., Klaue, A., Nezat, C.A., Driscoll, C.T., Johnson, C.E., Siccama, T.G., et al. 2002. Mycorrhizal weathering of apatite as an important calcium source in base-poor forest ecosystems. Nature 417, 729-731.

Borie, F., Rubio, R., Morales, A., Curaqueo, G., Cornejo, P. 2010. Arbuscular mycorrhizae in agricultural and forest ecosystems in Chile. J. soil. sci. plant nutr. 10, 185-206.

Borja, I., Nilsen, P. 2009. Long term effect of liming and fertilization on ectomicorrhizal colonization and tree growth in old scots pine (Pinus sylvestris L.) stand. Plant Soil 314, 109-119.

Callot, G. 1999. La truffe, la terre, la vie. INRA, Versailles. 210 pp. [En francés]

Canti, M.G. 2009. Experiments on the origin of ${ }^{13} \mathrm{C}$ in the calcium carbonate granules produced by the earthworm Lumbricus terrestris. Soil Biol Biochem 41, 2588-2592.
Casarin, V., Plassard, C., Hunsinger, P., Arvieu, J.C. 2004. Quantification of ectomycorrhizal fungal effects on the bioavailability and mobilization of soil $\mathrm{P}$ in the rhizosphere of Pinus pinaster. New Phytol 163, 177-185.

Douchafour, P., Souchier, B. 1979. Pédologie. 2. Constituants et Propriétés du Sol. Masson, Paris. 459 pp. [En francés].

Erland, S., Söderström, B. 1991. Effect of liming on ectomycorrhizal fungi infecting Pinus sylvestris L. 1. Mycorrhizal infection in limed humus in the laboratory and isolation of fungi from mycorrhizal roots. New Phytol 115, 675-682.

Follet, R.H., Murphy, L.S., Donahue, R.L. 1981. Fertilizers and soil amendments. Prentice-Hall, Englewood Cliffs. 557 pp.

García-Montero, L.G., Quintana, A., ValverdeAsenjo, I., Díaz, P. 2009. Calcareous amendments in truffle culture: A soil nutrition hypothesis. Soil Biol Biochem 41, 1227-1232.

Garcia-Montero, L.G., Valverde-Asenjo, I., GrandeOrtiz, M.A., Menta, C., Hernando, I. 2013. Impact of earthworm cast on soil $\mathrm{pH}$ and calcium carbonate in black truffle burns. Agroforest Sys, $87,815-826$.

Gaucher, G. 1971. Traité de pédologie agricole. Le sol ses caractéristiques agronomiques. Dunod, Paris, 578 pp. [En francés].

Gronflaten, L.K., Amundsen, L., Frank, J., Steinnes, E. 2005. Influence of liming and vitality fertilization on trace element concentrations in Scots pine forest soil and plants For Ecol Manag 213, 261-272. 
Hobbie, S.E., Peter, B.R., Oleksyn, J., Ogdahl, M., Zytkowiak, R., Hale, C., et al. 2006. Tree species effects on decomposition and forest floor dynamics in a common garden. Ecol 87, 2282297.

Hoffland, E., Giesler, R., Jongmans, T., Van Breemen, N. 2002. Increasing feldspar tunneling by fungi across a North Sweden podzol Chronosequence. Ecosys 5, 11-22.

Hoffland, E., Giesler, R., Jongmans, A.G., Van Breemen, N. 2003. Feldspar tunneling by fungi along natural productivity gradients. Ecosys 6, 739-746

Huettl, R.F., Zoettl, H.W. 1993. Liming as a mitigation tool in Germanýs declining forests-reviewing results from former and recent trials. For Ecol Manag 61, 325-338.

Jentschke, G., Marschner, P., Vodnik, D., Marth, C., Bredemeier, M., Rapp, C., et al. 1998. Lead uptake by Picea abies seedlings: effects of nitrogen source and mycorrhizas. J Plant Phys 153, 97-104.

Jongmans, A.G., Van Breemen, N., Lundström, U., Van Hees, P.A.W., Finaly, R.D., Srinivasan, M., et al. 1997. Rock-eating fungi. Nature 389, 682-683

Jonsson, T., Kokalj, S., Finlay, R., Erland, S. 1999. Ectomycorrhizal community structure in a limed spruce forest. Mycol Res 103, 501-508.

Kjoller, R., Clemmensen, K.E. 2009. Belowground ectomycorrhizal fungal communities respond to liming in three southern Swedish coniferous forest stands. For Ecol Manag 257. 2217-2225

Kreutzer, K. 1995. Effects of forest liming on soil processes. Plant Soil 168, 447-470.
Lang, C., Polle, A. 2011. Ectomycorrhizal fungal diversity, tree diversity and root nutrient relations in a mixed Central European forest. Tree Phys 31, 531-538.

Lee, H.C., Hong, C.O., Kim, S.Y., Schumacher, T., Kim, P.J. 2001. Reduction of phosphorous release by liming from temporary flooded rice rotational system in green house upland soil. Eco Engin 37, 1239-1243.

Löfgren, S., Cory, N., Zetterberg, T., Larsson, P.E., Kronnaïs, V. 2009. The long-term effects of catchment liming and reduced sulphur deposition on forest soils and runoff chemistry in southwest Sweden. For Ecol Manag 258, 567-578.

Loué, A. 1986. Les oligo-elements en agriculture. Nouvelle Librairie, Paris, 339 pp. [En francés].

Meriño-Gergichevich, C., Alberdi, M., Ivanov, A.G., Reyes-Díaz, M. 2010. $\mathrm{Al}^{3+}-\mathrm{Ca}^{2+}$ Interaction in plants growing in acid soils: al-phytotoxicity response to calcareous amendments. J. soil. sci. plant nutr. 10, 217-243.

Monfort-Salvador, I. 2013. Revisión bibliográfica sobre el impacto del calcio en la ecología de los hongos ectomicorrícicos. Tesis Fin de Máster. Universidad Politécnica de Madrid, Madrid. [En español].

Mrnka, L., Tokárová, H., Vosátka, M., Matejka, P. 2009. Interaction of soil filamentous fungi affects needle composition and nutrition of Norway spruce seedlings. Tree 23, 887-897

Naramabuye, F.X., Haynes, R.J., Modi, A.T. 2008. Cattle manure and grass residues as liming material in a semi.subsistence farming system. Agr Eco Envir 124, 136-141.

Nowotny, I., Dähne, J., Klingelhöfer, D., Rothe, G.M. 1998. Effect of artificial soil acidification and liming on growth and nutrient status of mycorrhizal roots of Norway spruce (Picea abies [L.] Karst.). Plant Soil 199. 29-40. 
Ostonen, I., Tedersoo, L., Suvi, T., Lohmus, K. 2009. Does a fungal species drive ectomycorrhizal root traits in Alnus spp.? Can J For Res 39, 1787-1796.

Qian, X.M., Kottke, I., Oberwinkler, F. 1998. Influence of liming and acidification on the activity of the mycorrhizal communities in a Picea abies (L.) Karst. Stand. Plant Soil 199, 99-109.

Rineau, F., Garbaye, J. 2009. Does forest liming impact the enzymatic profiles of ectomycorrhizal communities through specialized fungal symbionts?. Mycorrhiza 19, 493-500.

Rineau, F., Garbaye, J. 2010. Effects of liming on potential oxalate secretion and iron chelation of beech ectomycorrhizal root tips. Microb Eco 60. 331-339.

Rineau, F., Maurice, J.M., Nys, C., Voiry, H., Garbaye, J. 2010a. Forest liming durably impact the communities of ectomycorrhizas and fungal epigeous fruiting bodies. Ann For Sci 67. 110.

Rineau, F., Rose, C., Le Thiec, D., Garbaye, J. 2010b. Liming in a beech forest results in more mineral elements stored in the mantle of Lactarius subdulcis ectomycorrhizas. Fung Biol 114. 1007 1014.

Schneider, B.V., Zech, W. 1990. The influence of $\mathrm{Mg}$ fertilization on growth and mineral contents of fine roots in Picea abies (Karst. L.) stands at different stages of decline in NE-Bavaria. Water Air Soil Pol 54, 469-476.

Smits, M.M., Bonneville, S., Benning, L.G., Banwart, S.A., Leake, J.R. 2012. Plant-driven weathering of apatite - the role of an ectomycorrhizal fungus. Geobiol 5, 445-456.

Tuason, M.M.S., Arocena, J.M. 2009. Calcium Oxalate Biomineralization by Piloderma fallax in Response to Various Levels of Calcium and Phosphorus. App Envir Microb 75, 7079-7085.
Van Breemen, N., Finlay, R., Lundström, U., Jongmans, A.G., Giesler, R., Olsson, M. 2000a. Mycorrhizal weathering: A true case of mineral plant nutrition?. Biogeochemistry 49, 53-67.

Van Breemen, N., Lundström, U.S., Jongmans, A.G. 2000b. Do plants drive podzolization via rockeating mycorrhizal fungi?. Geoderma 94, 163171.

Van Schöll, L., Kuyper, W.T., Smits, M.M., Landeweert, R., Hoffland, E.,Van Breemen, N. 2008. Rock-eating mycorrhizas: their role in plant nutrition and biogeochemical cycles. Plant Soil 303, 35-47.

Wallander, H. 2000. Uptake of P from apatite by Pinus sylvestris seedlings colonised by different ectomycorrhizal fungi. Plant Soil 218, 249-256.

Wallander, H., Mahmood, S., Hagerberg, D., Johansson, L., Pallon, J. 2003. Elemental composition of ectomycorrhizal mycelia identified by PCR-RFLP analysis and grown in contact with apatite or wood ash in forest soil. FEMS Microb Eco 44, 57-65.

Wallander, H., Hagerberg, D., Aberg, G. 2006. Uptake of ${ }^{87} \mathrm{Sr}$ from microcline and biotite by ectomycorrhizal fungi in a Norway spruce forest. Soil Biol Biochem 38, 2487-2490.

Wedén, C., Pettersson, L., Danell, L. 2009. Truffle cultivation in Sweden: Results from Quercus robur and Corylus avellana field trials on the island of Gotland. Taylor and Francis 37-41.

Weigt, R.B., Raidl, S., Verma, R., Rodenkirchen, H., Göttlein. H. 2011. Effects of twice-ambient carbon dioxide and nitrogen amendment on biomass, nutrient contents and carbon costs of Norway spruce seedlings as influenced by mycorrhization with Piloderma croceum and Tomentellopsis submollis. Mycorrhiza 21, 375-391. 
Whitney, K.D., Arnott, H.J. 1987. Calcium oxalate crystal morphology and development in Agaricus bisporus. Mycologia 79, 180-187.

Wild, A. 1992. Russell's Soil Conditions and Plant Growth. Longman Group UK Limited, London: Longman Group UK Limited.

Zambrano, J.A., Dutra, M., Ribeiro, I., Lima, J.C., Felix de Barros, N., Chaer, A. 2009. Acúmulo de ácido oxálico e cristais de cálcio em ectomicorrizas de eucalipto. II formação de cristais de oxalato de cálcio induzida por fungos ectomicorrízicos em raízes laterais finas. Rev Brasileira Ciência Solo 33, 55-562.
Zhang, J., George, E. 2002. Changes in the extractability of cations $(\mathrm{Ca}, \mathrm{Mg}$ and $\mathrm{K})$ in the rhizosphere soil of Norway spruce (Picea abies) roots. Plant Soil 243, 209-217. 